Original Research Paper

\title{
Progress Made in Developing New High Yielding Potato Varieties for the Kenyan Highlands at KALRO-Tigoni
}

\author{
${ }^{1}$ Jane Muthoni and ${ }^{2}$ Hussein Shimelis \\ ${ }^{1}$ Kenya Agricultural and Livestock Research Organization (KALRO), Kenya \\ ${ }^{2}$ African Centre for Crop Improvement, University of KwaZulu-Natal, \\ College of Agriculture, Engineering and Science, School of Agricultural, \\ Earth and Environmental Sciences, Private Bag X01, Scottsxille 3209, Pietermaritzburg, South Africa
}

\author{
Article history \\ Received: 11-04-2018 \\ Revised: 01-06-2018 \\ Accepted: 20-06-2018 \\ Corresponding Author: \\ Jane Muthoni \\ Kenya Agricultural and \\ Livestock Research \\ Organization (KALRO), Kenya \\ Email: jayney480@yahoo.com
}

\begin{abstract}
Breeding has been going on at Kenya Agricultural and Livestock Research Institute (KALRO), Tigoni in Kenya to develop high yielding potato varieties that have good processing qualities. The objective was to develop high yielding potato varieties that are adapted to the Kenyan climatic and environmental conditions and that are suitable for processing. After initial crossing, the resultant families were evaluated for yield as well as crisping and chipping quality for three consecutive generations at KALRO-Tigoni; this resulted in selection of 112 candidate clones. The 112 selected clones (52 potentially for crisping) were then evaluated under Advanced Yield Trials (AYT) during the 2015 short rains season and 2016 long rains season at three sites (Tigoni, Molo and Meru). Yield data was analysed using the lattice procedure of Statistical Analysis Systems (SAS 9.1) statistical package. Genotype x Environment Interaction (GEI) as well as stability and adaptability of potato clones across sites was analysed using additive main effects and multiplicative interaction (AMMI) and genotype main effect and Genotype x Environment Interaction (GGE) biplot analysis. In the AYT, significant Genotype $x$ Environment Interactions (GEI) were observed. Clone G6 (2E87) was closest to the ideal genotype; it was the highest yielding and most stable while environment 2 (long rains season 2016 at KALRO-Tigoni) was the closest to ideal environment and therefore the most desirable of the six environments. From AYT, 18 clones were selected, 11 of them good for crisping. These clones were recommended for the National Performance Trials (NPT) before release of new varieties.
\end{abstract}

Keywords: Advanced Yield Trials, KALRO-Tigoni, Kenya, Potato Breeding

\section{Introduction}

\section{Background}

In Kenya, potato is an important food crop, second after maize in volumes produced (MoA, 1998; FAO, $2013 ; 2014)$. The crop is grown mainly as a cash and food crop by small-scale farmers, although some largerscale growers specialize in commercial production (FAO, 2014). Potato therefore plays an important role in food security (MoA, 2005; 2008; FAO, 2014) and is grown by about 800000 farmers, on 158000 ha per season, with an annual production of about 1.2 million tonnes in two growing seasons (Riungu, 2011; FAO, 2013; 2014; NPCK, 2014). The annual potato crop is valued at KES 13 billion (USD 150 million) at farm gate level and KES 40 billion (USD 362 million) at the consumer level (FAO, 2013; ANN, 2009). Potato farming in Kenya employs 3.3 million people at all levels of the value chain.

Potato therefore plays an important role in national food security and could ease pressure off the main cereal, maize. However, there has been a decline in potato production in Kenya (Gregory et al., 2013) because of a number of production constraints. These include low soil fertility, an inadequate supply of certified seeds, pests and diseases, low and erratic rainfall patterns as result of climate change and, the use of low yielding varieties (FAO, 2013).

There has been a long tradition of potato breeding in Kenya; screening and evaluation of imported European varieties and advanced clones from the International Potato Center (CIP) have been the most important 
sources of new varieties. Work done on potato breeding in Kenya in the sixties and seventies concentrated on major gene resistance to late blight; the varieties were meant for production in the high altitude areas of Kenya (MoALF, 2016). From these efforts, fourteen potato varieties from Western Europe were released in Kenya through the national potato research programme. However, these varieties were not well adapted to the local agro-climatic conditions mainly because they were the long-day Solanum tuberosum subsp. tuberosum (MoALF, 2016). In addition, these varieties had little resistance to late blight caused by Phytophthora infestans; the disease is a very serious production constraint throughout all the potato growing regions in Kenya. Furthermore, these potato varieties were very susceptible to bacterial wilt caused by Ralstonia solanacearum; the disease is becoming increasingly important not only in the low and medium potential areas but also in the high potential areas (Muthoni et al., 2013; MoA, 2005).

Between 1986 and 1997, adaptive research work was conducted at various stations in Kenya as a collaborative project between Kenya Agricultural Research Institute (KARI) and CIP. The main aim of these collaborative activities was to develop potato varieties with durable resistance to late blight, some level of tolerance to bacterial wilt and acceptable agronomic and postharvest qualities (FAO, 2013). These activities were carried out at the highland stations of KARI Tigoni and Mau Narok, at the mid-altitude stations of KARI Embu, KARI Kakamega and KARI Kabete and at low-altitude stations of KARI Mtwapa, Shimba Hills and KARI Katumani. The collaborative work resulted in the release of varieties Tigoni (for processing) and, Kenya Furaha and Asante (for domestic consumption). Subsequent collaboration with CIP resulted in release of 7 more varieties by 2010 (MoALF, 2016). Interestingly, a farmer variety, Shangi, which was formally released in Kenya in 2015, is the most popular and is grown by over $70 \%$ of potato farmers (Muthoni et al., 2013). Although the variety is fast maturing, it may not be best suited for processing industry.

Availability of suitable potato varieties for processing is important for the expansion of the processing sector in Kenya. The physical tuber quality, dry matter content and harvest maturity of potatoes are the determinants of the processing quality. The tuber shape, size and eye depth are important with regard to the appearance of the tubers and they determine the wastage that occurs during peeling (PSDA, 2009). Round tubers are preferred for crisping (chipping) while for making French fries, oval-shaped tubers are preferred. Currently, there is only one variety for making chips (French fries) (Tigoni) and one for making crisps (chips) (Dutch robyjn). However, Dutch robyjn is very susceptible to late blight, it is low yielding and has deep eyes leading to losses during peeling (PSDA,
2009). For the open air markets, white varieties are not preferred as they green easily.

Despite previous breeding efforts and import of seed potatoes from European countries, the impact of over 50 officially registered potato varieties in Kenya has not been realized. Imported varieties may not be well adapted to local conditions and may need high input levels for production. This may not be tenable especially with poor small scale farmers in Kenya. In addition, some of the imported varieties have been developed by private breeders and as such, issues of plant breeders' rights might hinder small scale farmers from engaging in commercial production of seeds of such varieties. There is need for continuous development of more locally adapted potato varieties that are high yielding and/or early maturing (for food security) and also to cater for the various processing industries. Consequently, development of new potato varieties was reinitiated with the reintroduction of cross-breeding activities in the national potato programme at KALRO-Tigoni (FAO, 2013). The objective of this research activity was to develop high yielding potato varieties that are adapted to the Kenyan climatic and environmental conditions and that are suitable for processing. The main focus is high yields, suitability for crisping and chipping and early maturity. Selection criteria are tuber yields (number and sizes), tuber shape, eye depth, skin colour and processing quality. Reported here are strides that have been made towards releasing new varieties.

\section{Methodology}

\section{Study Site}

The production of $\mathrm{F} 1$ potato seeds and the seedling multiplication were done at the Kenya Agricultural and Livestock Research Organization, Tigoni (KALROTigoni) [The organization was formerly Kenya Agricultural and Research Institute, KARI]. The KALRO-Tigoni station is located $40 \mathrm{~km}$ north-west of Nairobi city centre, at an altitude of $2051 \mathrm{~m}$ above sea level (masl) latitude of 10 9'7.22" South and longitude $36^{\circ} 41^{\prime} 8.72 "$ East (Jaetzold et al., 2006). The average annual rainfall is $1096 \mathrm{~mm}$ with a bimodal distribution. The long rainy season occurs between March and May, while the short rainy season is between October and December (Jaetzold et al., 2006). The mean annual air temperature is $18^{\circ} \mathrm{C}$ and ranges between 12 and $24^{\circ} \mathrm{C}$. The soil type is humic-nitosol (alfisol) derived from quartz trachyte (Jaetzold et al., 2006). The soil is very deep and well drained with a $\mathrm{pH}$ range of 5.5 to 6.5 . The soil is of medium inherent fertility with organic carbon content of $1.65 \%$. Exchangeable bases of potassium, calcium and magnesium are moderate to high with available potassium being about $21.2 \mathrm{ppm}$ (Jaetzold et al., 2006). 
Table 1: Name and source of the 14 potato parents used in the study

\begin{tabular}{lll}
\hline Parent & Germplasm maintainer & Male/Female \\
\hline Shangi & KALRO-Tigoni & Male \\
Kenya Karibu & KALRO-Tigoni & Male \\
Tigoni & KALRO-Tigoni & Male \\
Sherekea & KALRO-Tigoni & Male \\
Meru Mugaruro & KALRO-Tigoni & Male \\
Kihoro & KALRO-Tigoni & Male \\
Ingabire & KALRO-Tigoni & Male \\
Bishop Gitonga & KALRO-Tigoni & Male \\
391919.3 & CIP & Female \\
394904.9 & CIP & Female \\
394905.8 & CIP & Female \\
392278.19 & CIP & Female \\
394895.7 & CIP & Female \\
394903.5 & CIP & Female
\end{tabular}

$\overline{\mathrm{CIP}}=$ International Potato Center, KALROI-Tigoni $=$ Kenya Agricultural and Livestock Research Organization, Tigoni

\section{Plant Materials}

The study used 48 potato families developed as follows: Eight potato varieties selected previously from a bacterial wilt screening trial (Muthoni et al., 2014) were used as males. The eight varieties are high yielding and are popularly grown by Kenyan farmers but are highly susceptible to bacterial wilt (Muthoni et al., 2014). These males were crossed to a set of six female clones sourced from the International Potato Center (CIP) in Peru using a North Carolina mating design II (Table 1). Crossing was done to generate 48 families. Crossing was done in the field during the short rains season of 2012.

\section{Generation of True Potato Seed and F1 Seedlings}

A few days after crossing, berries started forming on successful crosses and about 40 days later, they were harvested. The harvested berries were stored in khaki paper bags for three weeks to soften before processing. The ripened berries were processed by cutting them with a knife and emptying the seeds into a basin containing clean water. The seeds were washed and then spread on filter papers and placed on a table in the laboratory to air-dry overnight. The following day, all the seeds from each cross family were soaked in 1500 ppm GA3 solution for $24 \mathrm{~h}$ to break dormancy. Thereafter they were rinsed and immediately sown in plastic trays containing sterilized sand. Watering was done using a can and the seedlings were sprayed against pests and diseases as required. Four weeks later, all the seedlings were transplanted from the plastic trays into the field at KALRO-Tigoni during the long rains season of 2013. Transplanting was done on 3rd April 2013.

\section{Field Management of the Seedling Generation}

The seedlings were transplanted in furrows at spacing of $75 \times 30 \mathrm{~cm}$. At transplanting, diammonium phosphate
(DAP) $\left(18 \% \quad \mathrm{~N}: \quad 46 \% \quad \mathrm{P}_{2} \mathrm{O}_{5}\right)$ was applied at the recommended rate of $500 \mathrm{~kg} \mathrm{ha}^{-1}$. Weeding, ridging and pests and late blight control were carried out as per recommendations for potato production in Kenya (KARI, 2008). When the crop was mature, it was harvested, each plant separately. From each cross family, 240 plants were randomly selected and from each selected plant, one tuber was retained. To break tuber dormancy, the tubers were treated by dipping them in a big container containing GA3 at 5 ppm for ten minutes. Thereafter, they were air-dried and covered with a black polythene sheet for one month. They were then uncovered until sprouting.

\section{Field Management and Selection of Clonal Generations}

The sprouted tubers were planted out in the field at KALRO-Tigoni during the 2013 short rains season so as to give the first clonal generation crop. The experimental materials consisted of the 48 families. These were planted in a $6 \times 8$ alpha lattice design replicated three times. Each plot consisted of 80 plants i.e., 8 rows each consisting of 10 plants. The tubers were planted in furrows at a spacing of $75 \times 30 \mathrm{~cm}$. During planting, DAP $\left(18 \% \mathrm{~N}: 46 \% \mathrm{P}_{2} \mathrm{O}_{5}\right)$ was applied at the recommended rate of $500 \mathrm{~kg} \mathrm{ha}^{-1}$. Weeding, ridging and pests and late blight control were carried out as per recommendations for potato production in Kenya (KARI, 2008). Supplemental irrigation was carried out when rainfall was not enough. When the crop was mature, it was harvested, each plant separately. At harvest, data collected were number of tubers per plant i.e. ware $(>45$ $\mathrm{mm}$ in diameter) and seed ( $<45 \mathrm{~mm}$ in diameter) and weight of different tuber sizes i.e., ware $(>45 \mathrm{~mm}$ in diameter) and seed ( $<45 \mathrm{~mm}$ in diameter). These were taken on the 20 middle plants per plot. Other features considered in the selection were tuber shape, tuber skin colour, number of eyes per tuber, tuber eye depth and general visual appearance of the tubers. This data collection and selection was carried out by a team consisting of two breeders, two socioeconomists, a food scientist, an agronomist and three field technical officers in charge of basic seed potato production. These people, all working at KALRO Tigoni, are well informed on potato production systems in Kenya and the needs of various ware potato markets. Based on the above agreed selection criteria, entire cross families that were inferior were rejected; 18 families were rejected. Of the accepted 30 families, 50 superior plants were selected from each family; these translated to 50 clones per selected family.

The selected families were planted out in the field at KALRO-Tigoni during the 2014 long rains season to generate second clonal generation. Each family was represented by the 50 selected clones. Each plot consisted of 50 rows i.e., clones and there was no 
replication. During harvesting, promising clones were selected. Selection of the promising clones was done in a participatory manner by stakeholders who were invited to undertake this exercise. The 40 stakeholders included the local farmers, traders from the local Limuru open air market, agricultural extension officers from Limuru sub county and local small-scale processors of chips and crisp. Selection criteria were tuber yields (numbers of different tuber sizes were counted), tuber shape, tuber eye depth, number of eyes per tuber and skin colour. Data was collected on the three middle rows per plot. These stakeholders selected a total of 542 clones across all the families.

In the following 2014 short rains season, the 542 clones were planted in the field at KALRO-Tigoni to give third clonal generation. All tubers in each of the clone selected in the second clonal generation were planted as one plot without replication. Field management of the crop was as in the previous generations. Supplemental irrigation was carried out when rainfall was not enough. Upon maturity, the crop was harvested. Yield data was taken i.e., total yield and the clones were later processed and tested for suitability for processing (crisps and chips) and fresh cooking (suitability for mashing). For crisping, chipping and fresh cooking evaluation, $5 \mathrm{~kg}$ of tubers from each clone were made into crisps, another $5 \mathrm{~kg}$ into chips and another $5 \mathrm{~kg}$ were boiled. Once ready, the samples were set out on trays for organoleptic testing. A panel 50 people conducted the sensory evaluation. The panel consisted of some members of staff at KALRO-Tigoni, some casual field labourers and some students who were on practical training at KALRO-Tigoni. Based on yield (over 35 ton/ha), processing quality (crisps and chips) and fresh cooking (mashing quality), 112 clones were selected (52 potentially for crisping) (Table 4). These 112 clones were then multiplied at KALRO Tigoni for one season during the 2015 long rains season to increase potato tuber quantities (fourth clonal generation). Field management of the crop was as in the previous generations. Upon crop maturity, yields data was taken (Table 4).
After multiplication, the 112 clones were planted out for Advanced Yield Trials (AYT) and stability studies during the 2015 short rains season and 2016 long rains season at three sites (Tigoni, Molo and Meru). The three sites differed in seasonality (Table 2). The three sites and two seasons formed six environments in which the AYT and stability studies were undertaken (Table 3). At each site and each season, each clone was planted in one ten-meter row consisting of ten plants. Field management of the crop was as in the previous generations but there was no supplemental irrigation. Upon crop maturity in each site and each season, the clones were harvested and yield data collected.

Genotype x Environment Interaction (GEI) Analysis AMMI Model

After harvesting advanced yield trials, yield data was subjected to Analysis of Variance (ANOVA) using the lattice procedure of Statistical Analysis Systems (SAS) statistical package (SAS, 2003) to determine the effects of environments, genotypes and Genotype $\mathrm{x}$ Environment Interaction (GEI) on potato tuber yields. Genotype stability was described using the Additive Main effects and Multiplicative Interaction (AMMI) model that combines into a single model analysis of variance (ANOVA) for genotype and environment main effects with Principal Component Analysis (PCA) for the GEI. The complete AMMI model is shown below (Crossa, 1990):

$$
Y_{i j}=\mu+g_{i}+e_{j}+\sum_{k=1}^{t} \lambda_{k} \alpha_{i k} \gamma_{j k}+\varepsilon_{i j}
$$

where, $Y_{i j}=$ is the mean yield $\left(t \mathrm{ha}^{-1}\right)$ of the $i^{\text {th }}$ genotype in the $j^{\text {th }}$ environment, $\mu$ is the overall mean, $g_{i}$ and $e_{j}$ are the main effects of the genotype and environment respectively, $t$ is the number of PCA axes considered, $\lambda_{\mathrm{k}}$ is the singular value of $k^{\text {th }}$ PCA axis, $\alpha_{i k}$ and $\gamma_{\mathrm{jk}}$ are scores for the $i^{\text {th }}$ genotype and $j^{\text {th }}$ environment on the $\mathrm{k}^{\text {th }}$ PCA axis and $\varepsilon_{i j}$ is the residual term which includes experimental error.

Table 2: Seasonality at Tigoni, Meru and Molo sites

\begin{tabular}{lll}
\hline Site & Long Rains (LR) season & Short rains (SR) season \\
\hline Tigoni & March-May & October-December \\
Marimba (Meru) & October-December & March-May \\
Marindas (Molo) & May-August & October-December \\
\hline
\end{tabular}

Table 3: Test environments in which advanced yield trials were conducted

\begin{tabular}{llllll}
\hline Tigoni SR 2015 & Tigoni LR 2016 & Meru LR 2015 & Meru SR 2016 & Molo SR 2015 & Molo LR 2016 \\
\hline ENVI 1 & ENVI 2 & ENVI 3 & ENVI 4 & ENVI 5 & ENVI 6 \\
\hline SR = short rains season, LR = long rains season, ENVI 1 = short rains season 2015 at Tigoni, ENVI 2 = long rains season 2016 at \\
Tigoni, ENVI 3 = long rains season 2015 at Meru, ENVI 4 = short rains season 2016 at Meru, ENVI 5 = short rains season 2015 at \\
Molo, ENVI 6 = long rains season 2016 at Molo
\end{tabular}


Table 4: Potato clones selected in the third clonal generation based on mean yields and crisping, chipping and fresh cooking quality and their performance during fourth clonal generation

\begin{tabular}{|c|c|c|c|c|c|c|c|c|}
\hline \multicolumn{6}{|c|}{ Third clonal generation } & \multicolumn{3}{|c|}{ Fourth clonal generation } \\
\hline Rank & Clone & Yields (ton ha ${ }^{-1}$ ) & Crisping & Chipping & Mashing & Rank & Clone & Yields (ton ha ${ }^{-1}$ ) \\
\hline 1 & $2 \mathrm{E} 87$ & 78.1 & & & & 1 & $2 \mathrm{E} 87$ & 87.1 \\
\hline 2 & $2 \mathrm{C} 20$ & 61.6 & & & & 2 & $2 \mathrm{C} 20$ & 76.7 \\
\hline 3 & $6 \mathrm{GA}$ & 52.6 & & & & 3 & $1 \mathrm{EU}$ & 53.9 \\
\hline 4 & $1 \mathrm{EU}$ & 47.8 & $\mathrm{X}$ & & & 4 & $6 \mathrm{GA}$ & 52.6 \\
\hline 5 & $6 \mathrm{CB}$ & 45.7 & & & & 5 & $5 \mathrm{E} 17$ & 50.2 \\
\hline 6 & $1 \mathrm{EY}$ & 45.4 & & & & 6 & $6 \mathrm{CB}$ & 50.1 \\
\hline 7 & 1HD1 & 44.3 & & $\mathrm{X}$ & $\mathrm{X}$ & 7 & 1B5 & 48.8 \\
\hline 8 & $5 \mathrm{E} 17$ & 44.2 & & $\mathrm{X}$ & & 8 & $6 \mathrm{~B} 17$ & 48.2 \\
\hline 9 & $2 \mathrm{C} 56$ & 44.2 & & & $\mathrm{X}$ & 9 & $2 \mathrm{C} 56$ & 48.0 \\
\hline 10 & $1 \mathrm{~B} 5$ & 44.1 & & & & 10 & $1 \mathrm{G} 45$ & 46.7 \\
\hline 11 & $6 \mathrm{H} 17$ & 43.9 & & & & 11 & $4 C 19$ & 45.9 \\
\hline 12 & $1 \mathrm{G} 45$ & 43.9 & & & & 12 & 5E08 & 45.5 \\
\hline 13 & $2 \mathrm{E} 68$ & 43.6 & & & & 13 & $1 \mathrm{EY}$ & 45.4 \\
\hline 14 & $5 \mathrm{~F} 38$ & 42.7 & & $\mathrm{X}$ & & 14 & 1HD1 & 45.4 \\
\hline 15 & $2 \mathrm{HH}$ & 42.5 & & & & 15 & $6 \mathrm{H} 22$ & 44.8 \\
\hline 16 & $1 \mathrm{EX}$ & 42.4 & $\mathrm{X}$ & & & 16 & $6 \mathrm{D} 45$ & 44.5 \\
\hline 17 & $5 \mathrm{E} 08$ & 42.3 & & & & 17 & $1 \mathrm{EX}$ & 44.4 \\
\hline 18 & $6 \mathrm{~B} 17$ & 42.2 & & & & 18 & $2 \mathrm{~B} 11$ & 43.4 \\
\hline 19 & $2 \mathrm{~B} 11$ & 42.1 & & & & 19 & 1B73A & 43.1 \\
\hline 20 & $1 \mathrm{C} 7$ & 42.0 & & & & 20 & $1 \mathrm{~F} 9$ & 43.0 \\
\hline 21 & $5 B 26$ & 41.6 & & $X$ & & 21 & 2E68 & 43.0 \\
\hline 22 & UK 5 & 41.5 & & & & 22 & $5 \mathrm{~B} 17$ & 42.9 \\
\hline 23 & $2 \mathrm{H} 21$ & 40.6 & & & & 23 & 1B14 & 42.9 \\
\hline 24 & $6 \mathrm{H} 22$ & 40.5 & & & & 24 & $5 C 39$ & 42.7 \\
\hline 25 & 1B73A & 40.1 & & & & 25 & $2 \mathrm{GC}$ & 42.6 \\
\hline 26 & $1 \mathrm{~B} 14$ & 39.9 & & & & 26 & $1 \mathrm{C} 7$ & 42.4 \\
\hline 27 & $2 \mathrm{GC}$ & 39.6 & & & & 27 & $6 \mathrm{H} 49$ & 42.3 \\
\hline 28 & $1 \mathrm{HC}$ & 39.6 & $\mathrm{X}$ & & & 28 & $5 F 38$ & 41.7 \\
\hline 29 & $1 \mathrm{~B} 67$ & 39.5 & & & $X$ & 29 & $2 \mathrm{H} 21$ & 41.6 \\
\hline 30 & $1 \mathrm{E} 02$ & 39.5 & $\mathrm{X}$ & & & 30 & $5 \mathrm{~B} 26$ & 41.6 \\
\hline 31 & $1 \mathrm{HG}$ & 39.4 & $X$ & & & 31 & $5 \mathrm{C} 5$ & 41.6 \\
\hline 32 & $6 \mathrm{H} 49$ & 39.2 & $X$ & & $\mathrm{X}$ & 32 & $2 \mathrm{HH}$ & 41.5 \\
\hline 33 & $2 \mathrm{AB}$ & 39.1 & & & & 33 & UK5 & 41.5 \\
\hline 34 & $1 \mathrm{~F} 9$ & 39.0 & & & & 34 & $1 \mathrm{HG}$ & 41.4 \\
\hline 35 & $1 \mathrm{HB} 1$ & 38.7 & $\mathrm{X}$ & & & 35 & $1 \mathrm{EV}$ & 41.1 \\
\hline 36 & $6 \mathrm{BA}$ & 38.6 & & & $\mathrm{X}$ & 36 & $6 \mathrm{~B} 170$ & 41.1 \\
\hline 37 & $6 \mathrm{C} 11$ & 38.5 & & & & 37 & 1E02 & 40.5 \\
\hline 38 & $6 \mathrm{C} 38$ & 38.3 & & & & 38 & $6 \mathrm{H} 17$ & 40.4 \\
\hline 39 & $2 \mathrm{~F} 40$ & 38.3 & & & & 39 & KE22 & 40.3 \\
\hline 40 & $1 \mathrm{~B} 87$ & 38.1 & & & & 40 & $1 \mathrm{~B} 87$ & 39.7 \\
\hline 41 & $5 \mathrm{~B} 17$ & 37.9 & & & & 41 & $6 \mathrm{D} 10$ & 39.7 \\
\hline 42 & $5 \mathrm{C} 5$ & 37.6 & & & & 42 & $1 \mathrm{HC}$ & 39.5 \\
\hline 43 & $6 \mathrm{D} 45$ & 37.5 & $\mathrm{X}$ & & & 43 & $2 \mathrm{C} 21$ & 39.3 \\
\hline 44 & $2 \mathrm{C} 21$ & 37.3 & & & & 44 & $1 \mathrm{~B} 67$ & 38.9 \\
\hline 45 & $6 \mathrm{C} 32$ & 37.2 & & $X$ & $X$ & 45 & 1HB1 & 38.9 \\
\hline 46 & $5 \mathrm{H} 61$ & 36.9 & & & & 46 & $2 \mathrm{AB}$ & 38.8 \\
\hline 47 & $6 \mathrm{D} 12$ & 35.8 & & & & 47 & $6 \mathrm{BA}$ & 38.7 \\
\hline 48 & $6 \mathrm{~B} 90$ & 35.3 & & $\mathrm{X}$ & $\mathrm{X}$ & 48 & $3 \mathrm{C} 22$ & 38.6 \\
\hline 49 & $5 \mathrm{C} 44$ & 35.3 & & & & 49 & $2 \mathrm{~F} 40$ & 38.4 \\
\hline 50 & $1 \mathrm{EV}$ & 35.1 & $\mathrm{X}$ & $X$ & $\mathrm{X}$ & 50 & $1 \mathrm{~F} 15$ & 38.4 \\
\hline 51 & $5 \mathrm{E} 07$ & 35.0 & & $X$ & & 51 & $5 \mathrm{C} 44$ & 37.8 \\
\hline 52 & $6 \mathrm{C} 25$ & 34.9 & $\mathrm{X}$ & & & 52 & $6 \mathrm{C} 11$ & 37.7 \\
\hline 53 & $5 \mathrm{~A} 2$ & 34.8 & $\mathrm{X}$ & & & 53 & $3 \mathrm{C} 21$ & 37.6 \\
\hline 54 & $5 \mathrm{C} 21$ & 33.3 & $\mathrm{X}$ & & & 54 & UK 4 & 37.5 \\
\hline 55 & 3 F29 & 33.2 & & & $X$ & 55 & $6 \mathrm{C} 32$ & 37.2 \\
\hline 56 & $1 \mathrm{~B} 96$ & 33.1 & $\mathrm{X}$ & & & 56 & $3 \mathrm{E} 03$ & 37.1 \\
\hline
\end{tabular}


Jane Muthoni and Hussein Shimelis / American Journal of Agricultural and Biological Sciences 2018, Volume 13: 50.63 DOI: 10.3844/ajabssp.2018.50.63

\begin{tabular}{|c|c|c|c|c|c|c|c|c|}
\hline 57 & $1 \mathrm{H} 1$ & 32.9 & $\mathrm{X}$ & $\mathrm{X}$ & & 57 & $5 \mathrm{H} 61$ & 36.9 \\
\hline 58 & $3 \mathrm{GA}$ & 32.6 & $\mathrm{X}$ & & $\mathrm{X}$ & 58 & $6 \mathrm{D} 47$ & 36.9 \\
\hline 59 & $2 \mathrm{~F} 35$ & 32.6 & & & $X$ & 59 & $5 \mathrm{C} 21$ & 36.8 \\
\hline 60 & UK 4 & 32.5 & $\mathrm{X}$ & & & 60 & $6 \mathrm{C} 38$ & 36.5 \\
\hline 61 & $5 \mathrm{E} 30$ & 32.4 & & $\mathrm{X}$ & & 61 & $6 \mathrm{H} 72$ & 36.5 \\
\hline 62 & KE22 & 32.3 & $\mathrm{X}$ & & & 62 & $1 \mathrm{HB}$ & 36.5 \\
\hline 63 & $4 \mathrm{DA}$ & 32.0 & $\mathrm{X}$ & & & 63 & $5 \mathrm{E} 30$ & 36.4 \\
\hline 64 & $6 \mathrm{D} 47$ & 31.9 & $\mathrm{X}$ & & & 64 & $6 \mathrm{~B} 90$ & 35.3 \\
\hline 65 & $1 \mathrm{G} 35$ & 31.8 & $\mathrm{X}$ & & & 65 & $6 \mathrm{D} 12$ & 34.8 \\
\hline 66 & $3 \mathrm{H} 1$ & 31.6 & & $X$ & & 66 & $5 \mathrm{~A} 2$ & 34.8 \\
\hline 67 & $1 \mathrm{~F} 15$ & 31.4 & & $\mathrm{X}$ & & 67 & $5 \mathrm{C} 15$ & 34.4 \\
\hline 68 & $6 C 30$ & 31.2 & $X$ & & $X$ & 68 & $5 \mathrm{E} 07$ & 34.4 \\
\hline 69 & $3 \mathrm{C} 22$ & 31.1 & $\mathrm{X}$ & & & 69 & $1 \mathrm{H} 1$ & 33.9 \\
\hline 70 & $6 \mathrm{D} 10$ & 30.7 & $\mathrm{X}$ & $X$ & & 70 & $6 \mathrm{C} 25$ & 33.9 \\
\hline 71 & $5 \mathrm{C} 15$ & 30.4 & $\mathrm{X}$ & $\mathrm{X}$ & & 71 & $6 \mathrm{GC}$ & 33.8 \\
\hline 72 & $1 \mathrm{HH} 1$ & 30.0 & & $\mathrm{X}$ & & 72 & $1 \mathrm{~B} 96$ & 33.1 \\
\hline 73 & $4 \mathrm{C} 19$ & 29.9 & & $\mathrm{X}$ & & 73 & $3 F 29$ & 32.2 \\
\hline 74 & $1 \mathrm{HB}$ & 29.7 & $\mathrm{X}$ & $\mathrm{X}$ & $\mathrm{X}$ & 74 & $3 \mathrm{C} 48$ & 31.7 \\
\hline 75 & $1 \mathrm{C} 48$ & 29.6 & $X$ & & & 75 & $6 \mathrm{C} 30$ & 31.2 \\
\hline 76 & $6 \mathrm{H} 78$ & 29.6 & $X$ & $\mathrm{X}$ & & 76 & $3 \mathrm{GA}$ & 31.2 \\
\hline 77 & $5 \mathrm{C} 39$ & 28.5 & $X$ & & & 77 & $2 F 35$ & 30.6 \\
\hline 78 & $1 \mathrm{G} 31$ & 28.4 & $X$ & & & 78 & $1 \mathrm{HH} 1$ & 30.0 \\
\hline 79 & $3 \mathrm{E} 03$ & 28.1 & & $X$ & $\mathrm{X}$ & 79 & $1 \mathrm{C} 48$ & 29.6 \\
\hline 80 & $1 \mathrm{G} 53$ & 28.0 & & & $\mathrm{X}$ & 80 & $6 \mathrm{H} 78$ & 29.6 \\
\hline 81 & $6 \mathrm{C} 29$ & 27.2 & $X$ & & & 81 & $4 \mathrm{DA}$ & 29.0 \\
\hline 82 & $3 \mathrm{C} 21$ & 26.6 & & & & 82 & $1 \mathrm{G} 31$ & 28.4 \\
\hline 83 & $3 \mathrm{~F} 3$ & 26.6 & $\mathrm{X}$ & $X$ & & 83 & $1 \mathrm{~F} 4$ & 27.7 \\
\hline 84 & 6GD & 26.5 & $X$ & & & 84 & $1 \mathrm{G} 53$ & 27.6 \\
\hline 85 & $2 \mathrm{~F} 19$ & 26.5 & & & $\mathrm{X}$ & 85 & $6 \mathrm{C} 29$ & 27.2 \\
\hline 86 & 1HA1 & 26.4 & $\mathrm{X}$ & & & 86 & $1 \mathrm{G} 35$ & 26.8 \\
\hline 87 & $3 \mathrm{H} 17$ & 25.9 & $\mathrm{X}$ & $\mathrm{X}$ & $X$ & 87 & $3 F 3$ & 26.6 \\
\hline 88 & $6 \mathrm{H} 58$ & 25.9 & & & $\mathrm{X}$ & 88 & 6GD & 26.5 \\
\hline 89 & $6 \mathrm{D} 43$ & 25.8 & $\mathrm{X}$ & & & 89 & $2 \mathrm{~F} 19$ & 26.5 \\
\hline 90 & $1 \mathrm{~F} 6$ & 25.8 & $\mathrm{X}$ & & & 90 & 1HA1 & 26.4 \\
\hline 91 & 1F77 & 25.8 & $X$ & & & 91 & $3 \mathrm{H} 17$ & 25.9 \\
\hline 92 & $6 \mathrm{GC}$ & 25.8 & & & $\mathrm{X}$ & 92 & $6 \mathrm{H} 58$ & 25.9 \\
\hline 93 & $2 \mathrm{C} 57$ & 25.4 & $X$ & & & 93 & $6 \mathrm{D} 43$ & 25.8 \\
\hline 94 & $4 \mathrm{E} 05$ & 23.9 & $\mathrm{X}$ & & & 94 & 1F77 & 25.8 \\
\hline 95 & $6 \mathrm{D} 44$ & 23.6 & $\mathrm{X}$ & & & 95 & $5 F 58$ & 25.6 \\
\hline 96 & $5 F 58$ & 21.6 & & $\mathrm{X}$ & & 96 & $3 \mathrm{H} 1$ & 25.6 \\
\hline 97 & $1 \mathrm{~F} 11$ & 20.3 & $\mathrm{X}$ & & & 97 & $2 \mathrm{C} 57$ & 25.4 \\
\hline 98 & $2 \mathrm{H} 4$ & 20.0 & $\mathrm{X}$ & & $\mathrm{X}$ & 98 & $4 \mathrm{E} 05$ & 23.9 \\
\hline 99 & $6 \mathrm{~B} 170$ & 19.1 & $\mathrm{X}$ & & & 99 & 1F6 & 22.8 \\
\hline 100 & $2 \mathrm{C} 24$ & 18.7 & $X$ & & & 100 & $6 \mathrm{D} 44$ & 22.6 \\
\hline 101 & $1 F 57$ & 18.7 & $X$ & & & 101 & $2 \mathrm{C} 24$ & 22.4 \\
\hline 102 & $3 \mathrm{C} 48$ & 17.8 & & $X$ & & 102 & $5 \mathrm{E} 87$ & 21.3 \\
\hline 103 & $5 \mathrm{H} 1$ & 17.6 & $X$ & & & 103 & $1 F 11$ & 20.3 \\
\hline 104 & $1 \mathrm{~F} 4$ & 17.5 & $\mathrm{X}$ & & $X$ & 104 & $2 \mathrm{H} 4$ & 20.0 \\
\hline 105 & $6 \mathrm{~B} 55$ & 17.4 & $X$ & & & 105 & $1 \mathrm{~F} 57$ & 18.7 \\
\hline 106 & $6 \mathrm{~B} 37$ & 16.2 & & $\mathrm{X}$ & & 106 & $5 \mathrm{H} 1$ & 17.6 \\
\hline 107 & $1 \mathrm{C} 47$ & 15.9 & $X$ & & & 107 & $6 \mathrm{~B} 55$ & 17.4 \\
\hline 108 & $6 \mathrm{H} 72$ & 14.3 & & $\mathrm{X}$ & & 108 & $1 \mathrm{H} 11$ & 16.7 \\
\hline 109 & $3 \mathrm{C} 20$ & 14.2 & $X$ & & & 109 & $3 \mathrm{C} 20$ & 16.2 \\
\hline 110 & $1 \mathrm{HK}$ & 13.0 & $\mathrm{X}$ & $\mathrm{X}$ & & 110 & $6 \mathrm{~B} 37$ & 16.2 \\
\hline 111 & $5 \mathrm{E} 87$ & 11.3 & $\mathrm{X}$ & & & 111 & $1 \mathrm{C} 47$ & 15.9 \\
\hline \multirow[t]{2}{*}{112} & $1 \mathrm{HH}$ & 10.1 & & $\mathrm{X}$ & & 112 & $1 \mathrm{HK}$ & 12.1 \\
\hline & Mean & 33.1 & & & & & Mean & 35.7 \\
\hline
\end{tabular}

From this model, AMMI Analysis of Variance (ANOVA) that showed significance of genotypes, environments and GEI was presented to interpret the results; also presented was the ranking of potato 
clones depending on their performance in different environments. The AMMI 2 showing the first and second Interaction Principal Components Axes (IPCA 1 and IPCA 2) was also presented to assess the interaction of the potato clones with the test environments.

\section{GGE Biplot}

Performance of potato clones across the environments was also explained using genotype main effect $(G)$ and Genotype $x$ Environment interaction (GGE) biplot analysis based on the principal component analysis (PCA) of environment-centred data (Yan et al., 2000; Yan, 2002). The GGE biplots display both Genotype (G) and Genotype $x$ Environment (GE) interactions which are the two main sources of variation that are relevant for genotype evaluation (Kang, 1993; Yan et al., 2007). The GGE biplot analysis was done using Genstat statistical package (14 ${ }^{\text {th }}$ Edition) (Payne et al., 2011). The GGE mathematical model based on PCA of environment-centred data (which contains $G$ and $G E$ as the main sources of variation) subjected to Singular Value Decomposition (SVD) was used to visualize the relationship among potato clones and the environments. The basic model for a GGE biplot as described by Yan (2002) is:

$$
Y_{i j}-\mu-\beta_{j}+\sum_{l=1}^{k} \lambda_{l} \gamma_{i l} \eta_{l j}+\varepsilon_{i j}
$$

Where:

$Y_{i j}=$ Mean tuber yield $\left(t \mathrm{ha}^{-1}\right)$ of the $i^{\text {th }}$ genotype in the $j^{\text {th }}$ environment

$\mu=$ Overall mean

$\beta_{j}=$ Main effect of the environment

$\lambda_{l}=$ Eigen value associated with IPCA $l$

$\gamma_{i l}=$ The eigen vector of genotype $i$ for PC $l$

$\eta_{l j}=$ The eigenvector of environment $j$ for PC $l$

$\varepsilon_{i j}=$ Error term associated with potato genotype $i$ in environment $j$.

Interrelationships among the test environments (Cooper et al., 1997) and potato clones (Yan et al., 2001) were visualised using various GGE biplot graphs. A GGE polygon was used to identify high yielding clones in specific environments through analysis of the "which-won-where-pattern" (Yan et al., 2000; Yan, 2002). The GGE biplots based on Average Environment Coordination (AEC) and drawn on the genotype-focused biplot (Yan and Kang, 2003) was used to determine yield performance and stability of the 112 potato clones. Environment-focused scaling was used to test the relationship of the test environments.

\section{Results}

\section{Selection of Potato Clones in Clonal Generations}

Of the clones selected in the third clonal generation 50 clones $\left(44.6 \%\right.$ ) had yields more than 35 ton $\mathrm{ha}^{-1}$ (Table 4).

During the fourth clonal generation, 64 clones (57.1\%) yielded more than 35 ton $\mathrm{ha}^{-1}$ (Table 4 ). The fourth clonal generation had higher mean yield (35.7 ton $\mathrm{ha}^{-1}$ ) than the third clonal generation possibly due to the higher rainfall which were experienced during the fourth clonal generation. As far as the yields were concerned, some clones ranked differently between the two clonal generations. For example 6D45, 1EU and 4C19 ranked differently between the two generations.

\section{Stability Analysis of Clones in Advanced Yield Trials AMMI Analysis of Variance}

The AMMI analysis of variance showed significant $(p \leq 0.001)$ effects of the genotypes $(G)$, environments (E) and the G x E interaction (Table 5). Of the AMMI model (treatment) sum of squares, the genotypes contributed $41.52 \%$, the environments $27.91 \%$ and the $G \times E$ interaction $30.56 \%$. The IPCA1 was significant $(\mathrm{p} \leq 0.001)$ and it explained $10.76 \%$ of the treatment sum of squares which is $35.21 \%$ of the $\mathrm{G} \times \mathrm{E}$ interaction sum of squares. The IPCA 2 was also significant $(\mathrm{p} \leq 0.001)$ and it explained $7.77 \%$ of the treatment sum of squares which is $25.41 \%$ of the $\mathrm{G} \times \mathrm{E}$ interaction sum of squares. Combined, the IPCA 1 and IPCA 2 explained $60.62 \%$ of the total $\mathrm{G} \times \mathrm{E}$ interaction. Therefore AMMI 2 was used to describe the $G \times E$ interaction. The AMMI 2 utilizes the genotypic and environmental main effects to describe additive variation and two interaction principal component axes (IPCA 1 and IPCA 2) for the non-additive variation.

\section{Ranking of the Best Four AMMI Selections Per Environment}

There were differences in the ranking of potato clones for tuber yields across the six test environments (Table 6); this indicates crossover interactions. Environments 4, 1, 6 and 2 ranked clone G6 (clone 2E87) first.

Clone G6 (2E87) gave the highest mean yields across the six test environments (Table 7). Eight clones yielded more than $40 \mathrm{t} \mathrm{ha}^{-1}$.

\section{AMMI Biplots: Classification of Clones and Environments}

Clone G20 was the winner in ENVI 1, ENVI 4 and ENVI 6 while clone G6 was the winner in the ENVI 2 (Fig. 1). Clone G6 showed a high and positive interaction with ENVI 2 whereas G47, G24, G52, G70 and G32 interacted positively with ENVI 3. Most potato clones had 
IPCA values between +1.0 and -1.0 indicating low interaction with the test environments. The ENVI 1, ENVI 4 and ENVI 6 clustered together indicating similar performance of genotypes in these environments. In addition, the three environments showed low interactive behaviour with the test genotypes.

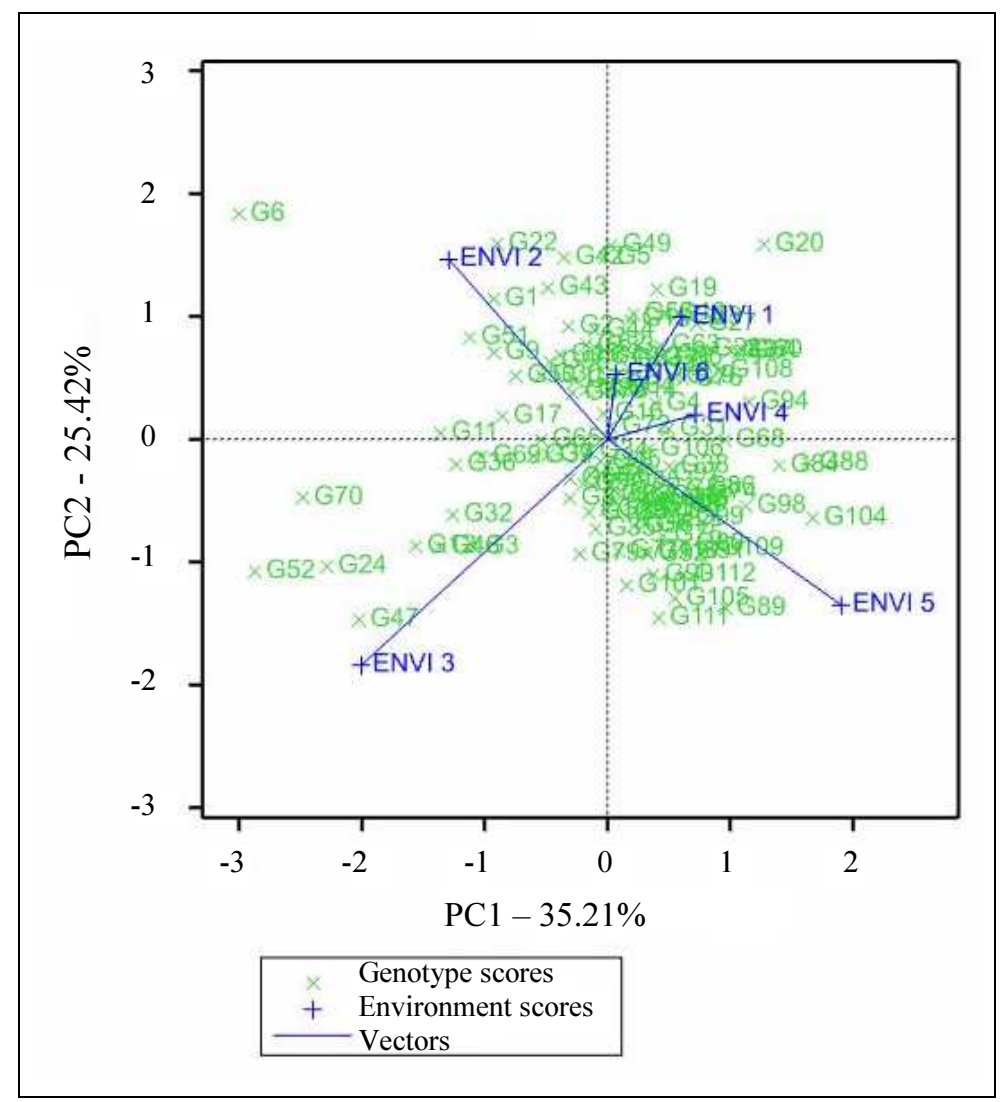

Fig. 1: AMMI 2 biplot of yields of 112 potato clones (G1-G112) across the six environments (ENVI 1-ENVI 6)

Table 5: Analysis of variance for potato tuber yields $\left(\mathrm{t} \mathrm{ha}^{-1}\right)$ for 112 potato clones grown in six test environments

\begin{tabular}{|c|c|c|c|c|c|}
\hline Source & d.f. & S.S. & m.s. & $\begin{array}{l}\% \text { treatment } \\
\text { SS explained }\end{array}$ & $\begin{array}{l}\% \mathrm{G} \times \mathrm{E} \text { interaction } \\
\text { SS explained }\end{array}$ \\
\hline Treatments & 671 & 59464 & 88.62 & & \\
\hline Genotypes (G) & 111 & 24692 & $222.5 * * *$ & 41.52 & \\
\hline Environments (E) & 5 & 16597 & $3319.4 * * *$ & 27.91 & \\
\hline Interactions ( $\mathrm{G} \times \mathrm{E})$ & 555 & 18175 & $32.75 * * *$ & 30.56 & \\
\hline IPCA 1 & 115 & 6400 & $55.6^{* * *}$ & $(10.76)$ & 35.21 \\
\hline IPCA 2 & 113 & 4619 & $40.9 * * *$ & $(7.77)$ & 25.41 \\
\hline Interactions residuals & 327 & 7156 & 21.9 & $(17.33)$ & 39.37 \\
\hline
\end{tabular}

$\mathrm{df}=$ Degrees of freedom; $* * *=$ Significant at $\mathrm{p} \leq 0.001 ; \mathrm{ns}=$ Non significant; $\mathrm{SS}=$ Sum of Squares, MS $=$ Mean Squares

Table 6: The best four potato clones from AMMI per environment

\begin{tabular}{|c|c|c|c|c|c|}
\hline \multirow[b]{2}{*}{ Environment } & \multirow[b]{2}{*}{ Mean yields $\left(\mathrm{t} \mathrm{ha}^{-1}\right)$} & \multicolumn{4}{|c|}{ Rank } \\
\hline & & 1 & 2 & 3 & 4 \\
\hline ENVI 5 & 23.96 & G61 & G3 & G47 & G35 \\
\hline ENVI 4 & 27.53 & G6 & G47 & $\mathrm{G} 2$ & G3 \\
\hline ENVI 1 & 30.48 & G6 & $\mathrm{G} 2$ & $\mathrm{G} 3$ & G4 \\
\hline ENVI 6 & 38.25 & G6 & G47 & $\mathrm{G} 2$ & G3 \\
\hline ENVI 2 & 35.41 & G6 & G47 & G2 & G1 \\
\hline ENVI 3 & 35.27 & G47 & G52 & G24 & G6 \\
\hline
\end{tabular}


Jane Muthoni and Hussein Shimelis / American Journal of Agricultural and Biological Sciences 2018, Volume 13: 50.63 DOI: 10.3844/ajabssp.2018.50.63

Table 7: Performance of potato clones across the six environments

\begin{tabular}{|c|c|c|c|}
\hline Genotype code & clone & Mean yields $\left(\mathrm{t} \mathrm{ha}^{-1}\right)$ & Rank \\
\hline G6 & $2 \mathrm{E}+87$ & 51.81 & 1 \\
\hline G47 & $4 \mathrm{C} 19$ & 48.1 & 2 \\
\hline G3 & $1 \mathrm{EY}$ & 45.49 & 3 \\
\hline G2 & $1 \mathrm{EX}$ & 42.98 & 4 \\
\hline G48 & $1 \mathrm{~F} 15$ & 42.74 & 5 \\
\hline $\mathrm{G} 24$ & $2 \mathrm{E}+68$ & 42.61 & 6 \\
\hline G52 & $1 \mathrm{EU}$ & 40.84 & 7 \\
\hline G12 & $6 \mathrm{~B} 170$ & 40.08 & 8 \\
\hline G4 & $6 \mathrm{CB}$ & 39.47 & 9 \\
\hline G7 & $3 \mathrm{E}+03$ & 39.38 & 10 \\
\hline G8 & $1 \mathrm{HG}$ & 39.38 & 11 \\
\hline G1 & $5 C 39$ & 39.31 & 12 \\
\hline G35 & $5 \mathrm{E}+17$ & 39.26 & 13 \\
\hline G61 & $6 \mathrm{D} 47$ & 38.99 & 14 \\
\hline G70 & $3 \mathrm{C} 48$ & 38.73 & 15 \\
\hline G50 & $6 \mathrm{D} 10$ & 38.62 & 16 \\
\hline G32 & $3 \mathrm{C} 22$ & 38.58 & 17 \\
\hline G9 & $2 \mathrm{HH}$ & 37.38 & 18 \\
\hline $\mathrm{G} 25$ & $1 \mathrm{G} 53$ & 37.02 & 19 \\
\hline G14 & $1 \mathrm{EV}$ & 36.98 & 20 \\
\hline G18 & $1 \mathrm{E}+02$ & 36.90 & 21 \\
\hline G15 & 1B73A & 36.84 & 22 \\
\hline G51 & $6 \mathrm{H} 78$ & 36.79 & 23 \\
\hline G42 & $6 \mathrm{H} 72$ & 36.48 & 24 \\
\hline G13 & $6 \mathrm{~B} 17$ & 36.42 & 25 \\
\hline G43 & $1 \mathrm{~B} 96$ & 36.36 & 26 \\
\hline G69 & $1 \mathrm{HB}$ & 36.25 & 27 \\
\hline G5 & $6 \mathrm{D} 45$ & 36.19 & 28 \\
\hline G10 & $1 \mathrm{~F} 9$ & 35.80 & 29 \\
\hline G38 & $6 \mathrm{D} 43$ & 35.70 & 30 \\
\hline G31 & $5 \mathrm{C} 5$ & 35.54 & 31 \\
\hline G11 & $5 F 38$ & 35.26 & 32 \\
\hline G77 & $1 \mathrm{HC}$ & 35.24 & 33 \\
\hline G17 & $1 \mathrm{G} 45$ & 34.95 & 34 \\
\hline G46 & 1B87 & 34.95 & 35 \\
\hline G36 & 1HD1 & 34.61 & 36 \\
\hline G33 & $5 \mathrm{E}+07$ & 34.35 & 37 \\
\hline G44 & $2 \mathrm{~F} 40$ & 34.08 & 38 \\
\hline G75 & $3 \mathrm{~F} 3$ & 34.03 & 39 \\
\hline G62 & 1B67 & 34.02 & 40 \\
\hline G39 & $6 \mathrm{GA}$ & 33.61 & 41 \\
\hline G30 & $2 \mathrm{C} 56$ & 33.46 & 42 \\
\hline G80 & $2 \mathrm{C} 24$ & 33.38 & 43 \\
\hline G45 & $5 \mathrm{C} 21$ & 33.28 & 44 \\
\hline G65 & $6 C 38$ & 33.21 & 45 \\
\hline G74 & $2 \mathrm{~F} 35$ & 33.00 & 46 \\
\hline $\mathrm{G} 27$ & 1HB1 & 32.85 & 47 \\
\hline G49 & $6 \mathrm{D} 12$ & 32.78 & 48 \\
\hline G26 & $5 \mathrm{H} 61$ & 32.58 & 49 \\
\hline G28 & $2 \mathrm{H} 21$ & 32.42 & 50 \\
\hline G23 & KE22 & 32.31 & 51 \\
\hline G67 & $6 \mathrm{C} 11$ & 32.17 & 52 \\
\hline G55 & $5 \mathrm{~B} 17$ & 32.15 & 53 \\
\hline G29 & $2 \mathrm{C} 20$ & 32.06 & 54 \\
\hline G21 & $5 \mathrm{C} 15$ & 31.85 & 55 \\
\hline
\end{tabular}

Table 7: Continue

\begin{tabular}{llll}
\hline G78 & $1 \mathrm{~F} 4$ & 31.76 & 56
\end{tabular}

G34 $\quad 5 \mathrm{E}+08 \quad 31.39 \quad 57$

$\begin{array}{llll}\mathrm{G} 40 & 6 \mathrm{~B} 90 & 31.37 & 58\end{array}$

G71 $\quad 5 \mathrm{E}+30 \quad 31.26 \quad 59$

$\begin{array}{llll}\text { G57 } & 1 \mathrm{~B} 5 & 31.22 & 60\end{array}$

G53

G16

G86

G66

G81

G59

G64

G73

G79

G68

G56

G54

G58

G60

G76

G83

G92

G20

G72

G85

G22

G41

G82

G63

G19

G91

G89

G96

G37

G84

G87

G97

G90

G93

G100

G88

G102

G101

G103

G106

G107

G98

G99

G111

G95

G105

G112

$3 \mathrm{C} 21 \quad 31.19$

60

61

$\begin{array}{lll}6 \mathrm{H} 49 & 31.01 & 62\end{array}$

$\begin{array}{lll}6 \mathrm{D} 44 & 30.88 & 63\end{array}$

$\begin{array}{lll}5 \mathrm{C} 44 & 30.81 & 64\end{array}$

$\begin{array}{lll}6 \mathrm{GC} & 30.79 & 65\end{array}$

$\begin{array}{lll}6 \mathrm{C} 32 & 30.76 & 66\end{array}$

$\begin{array}{lll}6 \mathrm{C} 32 & 30.76 & 66 \\ 6 \mathrm{C} 25 & 30.67 & 67\end{array}$

$\begin{array}{lll}6 \mathrm{H} 58 & 30.67 & 68\end{array}$

$\begin{array}{lll}\text { 1HA1 } & 30.29 & 69\end{array}$

$\begin{array}{lll}4 \mathrm{E}+05 & 30.20 & 70\end{array}$

$\begin{array}{lll}1 \mathrm{~B} 14 & 30.12 & 71\end{array}$

$\begin{array}{lll}\text { UK } 4 & 29.94 & 72\end{array}$

$\begin{array}{lll}6 \mathrm{H} 22 & 29.05 & 73\end{array}$

$\begin{array}{lll}6 \mathrm{C} 30 & 28.91 & 74\end{array}$

$\begin{array}{lll}1 \mathrm{~F} 77 & 28.90 & 75\end{array}$

$\begin{array}{lll}5 \mathrm{E}+87 & 28.37 & 76\end{array}$

$\begin{array}{lll}1 \mathrm{~F} 57 & 28.31 & 77\end{array}$

$\begin{array}{lll}3 \mathrm{GA} & 28.27 & 78\end{array}$

$\begin{array}{lll}1 \mathrm{H} 1 & 28.25 & 79\end{array}$

$\begin{array}{lll}6 \mathrm{H} 17 & 28.08 & 80\end{array}$

$\begin{array}{lll}\text { UK5 } & 27.61 & 81\end{array}$

$\begin{array}{lll}6 \mathrm{C} 29 & 27.42 & 82\end{array}$

$\begin{array}{lll}6 \mathrm{BA} & 27.26 & 83\end{array}$

$\begin{array}{lll}3 \mathrm{H} 1 & 27.14 & 84\end{array}$

$\begin{array}{lll}3 \mathrm{AB} & 27.10 & 85\end{array}$

$\begin{array}{lll}6 \mathrm{GD} & 26.97 & 86\end{array}$

$\begin{array}{lll}2 \mathrm{C} 21 & 26.86 & 87\end{array}$

$\begin{array}{lll}2 \mathrm{C} 21 & 26.86 & 87 \\ 3 \mathrm{H} 17 & 26.71 & 88\end{array}$

$\begin{array}{lll}5 \mathrm{~B} 26 & 26.67 & 89\end{array}$

$\begin{array}{lll}5 \mathrm{H} 1 & 26.61 & 90\end{array}$

$\begin{array}{lll}1 H H 1 & 26.50 & 91\end{array}$

$\begin{array}{lll}1 \mathrm{~F} 11 & 26.44 & 92\end{array}$

$\begin{array}{lll}2 \mathrm{C} 57 & 26.04 & 93\end{array}$

$\begin{array}{lll}3 \mathrm{C} 20 & 25.81 & 94\end{array}$

$\begin{array}{lll}2 \mathrm{~F} 19 & 25.60 & 95\end{array}$

$\begin{array}{lll}2 \mathrm{~F} 19 & 25.60 & 96\end{array}$

$\begin{array}{lll}6 \mathrm{~B} 55 & 25.24 & 97\end{array}$

$\begin{array}{lll}1 \mathrm{C} 48 & 24.60 & 98\end{array}$

$\begin{array}{lll}1 C 48 & 24.60 & 99 \\ 5 \mathrm{~F} 58 & 24.48 & 99\end{array}$

$\begin{array}{lll}6 \mathrm{~B} 37 & 24.46 & 100\end{array}$

$\begin{array}{lll}5 \mathrm{~A} 2 & 24.06 & 101\end{array}$

$\begin{array}{lll}5 \mathrm{~A} 2 & 24.06 & 102 \\ 2 \mathrm{GC} & 24.05 & 103\end{array}$

$\begin{array}{lll}1 \mathrm{C} 7 & 23.45 & 103\end{array}$

$\begin{array}{lll}1 \mathrm{HK} & 23.10 & 104\end{array}$

$\begin{array}{lll}1 \mathrm{G} 31 & 23.09 & 105\end{array}$

$\begin{array}{lll}1 \mathrm{C} 47 & 21.73 & 108\end{array}$

$\begin{array}{llll}\text { G94 } & \text { 2B11 } & 21.70 & 109\end{array}$

$\begin{array}{llll}\text { G108 } & 1 \mathrm{G} 35 & 21.17 & 110\end{array}$

$\begin{array}{llll}\text { G110 } & 2 \mathrm{H} 4 & 20.50 & 111\end{array}$

\begin{tabular}{llll} 
G104 & IF6 & 19.29 & 112 \\
\hline
\end{tabular}




\section{GGE Biplot Analysis: Winning Genotypes and Mega-Environments}

In the GGE analysis, IPCA 1 contributed $66.37 \%$ while IPCA 2 accounted for $11.07 \%$ of the total variation. The GGE biplot therefore explained $77.45 \%$ of the $G$ and $G \times E$ interaction variation (Fig. 2). Based on biplot analysis, two mega-environments are suggested. The first mega environment contains environments ENVI 1, ENVI 2, ENVI 4 and ENVI 6 while the second mega environment contains environments ENVI 3 and ENVI 5. Potato clone G6 was the winner in the first mega environment while clones G47 and G52 were the winners in the second mega environment. This means that clone G6 (6CB) is the most specifically suited to the first mega environment and clones G47 and G52 are specifically suited to the second mega environment. Other clones that are specifically suited to the second mega environment are G3, G70, G32, G24 and G48.

The most discriminating environments were ENVI 3 and ENVI 2 (Fig. 3). ENVI 5 was the least discriminating and hence least informative; genotypic differences in ENVI 5 may not be reliable for selection purposes. In addition, ENVI 4, ENVI 6 and ENVI 2 are quite similar; with limited funds, ENVI 4 and ENVI 6 could be dropped.

The ENVI 2 was the closest to ideal environment and therefore the most desirable of the six environments (Fig. 4). It had great discriminating power and was representative of the test environments. ENVI 5 was the least informative. The ENVI 3 did not appear representative of other environments. However, since it had the longest vector, it had the most discriminating power; it was also a unique environment.

Clone G6 (2E87) was closest to the ideal genotype; it was the highest yielding and most stable (Fig. 5). It was followed by clones G47, G3, G48, G24, G70 and G52.

Based on the yield data across the test environments and the suitability for crisping and chipping, 18 potato clones were selected (Table 8). These clones will be subjected to National Performance Trials (NPT) before release of new varieties.

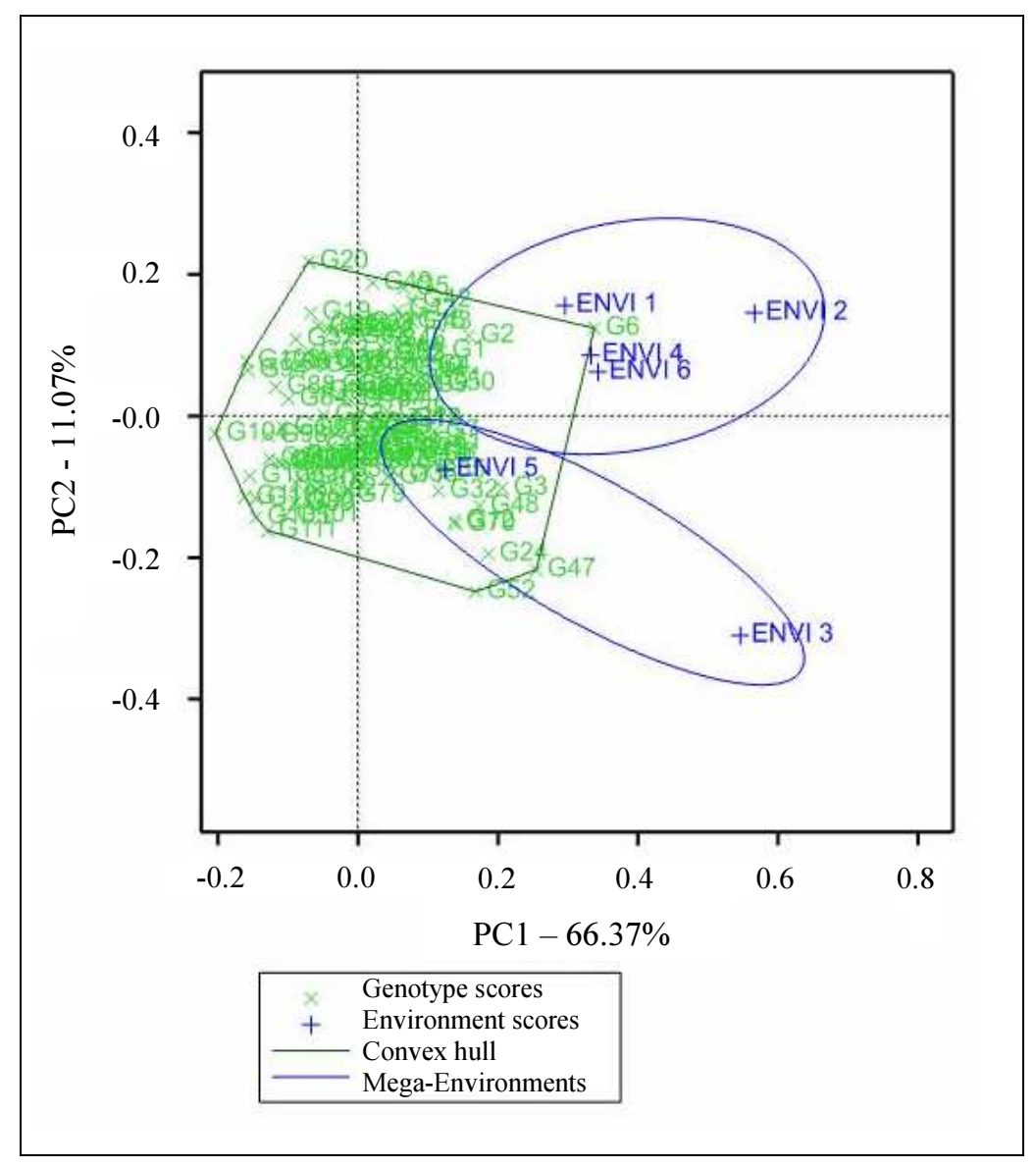

Fig. 2: The which-won-where || view of the GGE biplot under each mega-environment constructed based on environment-centred and symmetrical singular-value partitioning 


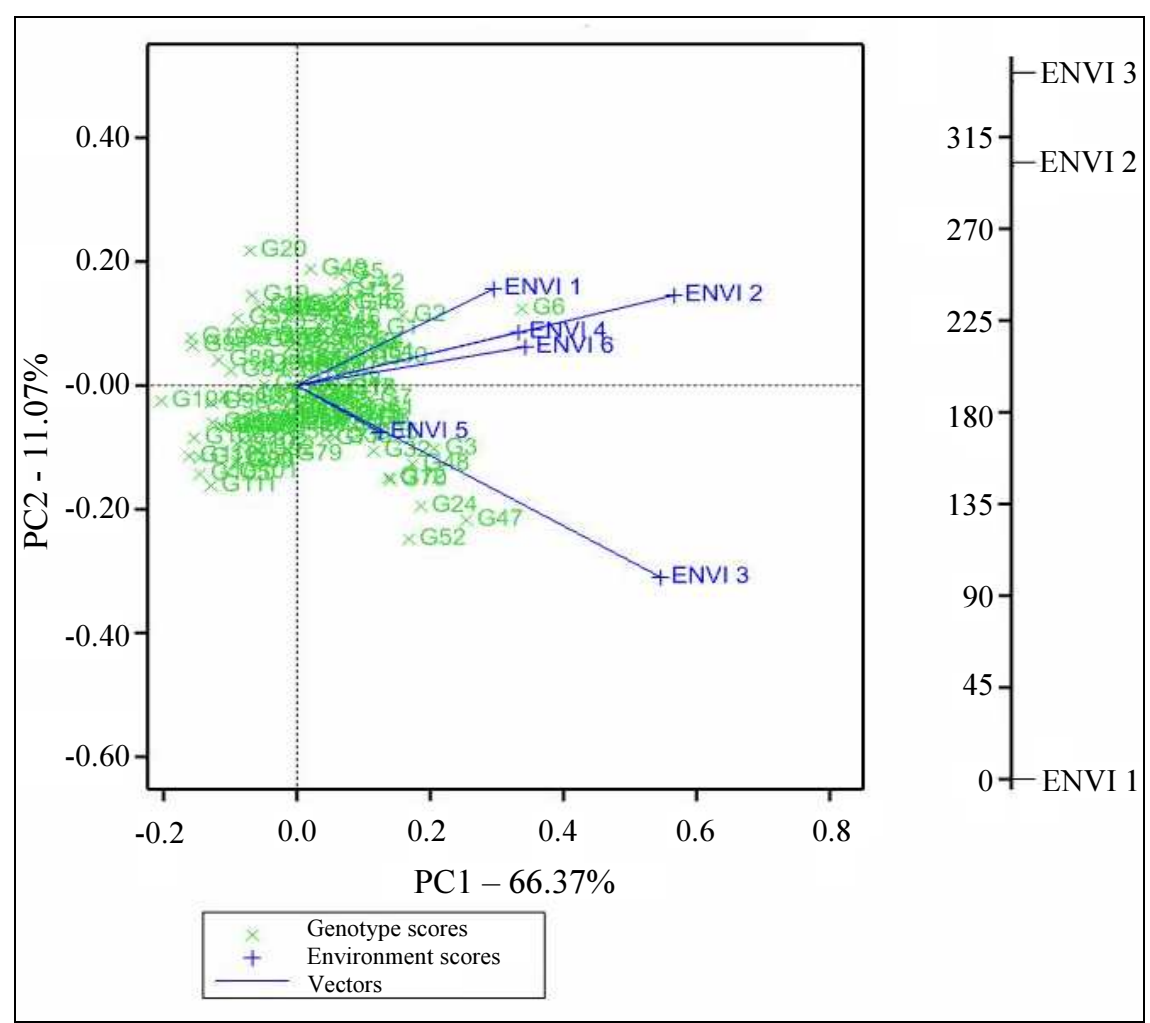

Fig. 3: Vector view of the GGE biplot showing the discriminating power and representativeness of the test environments

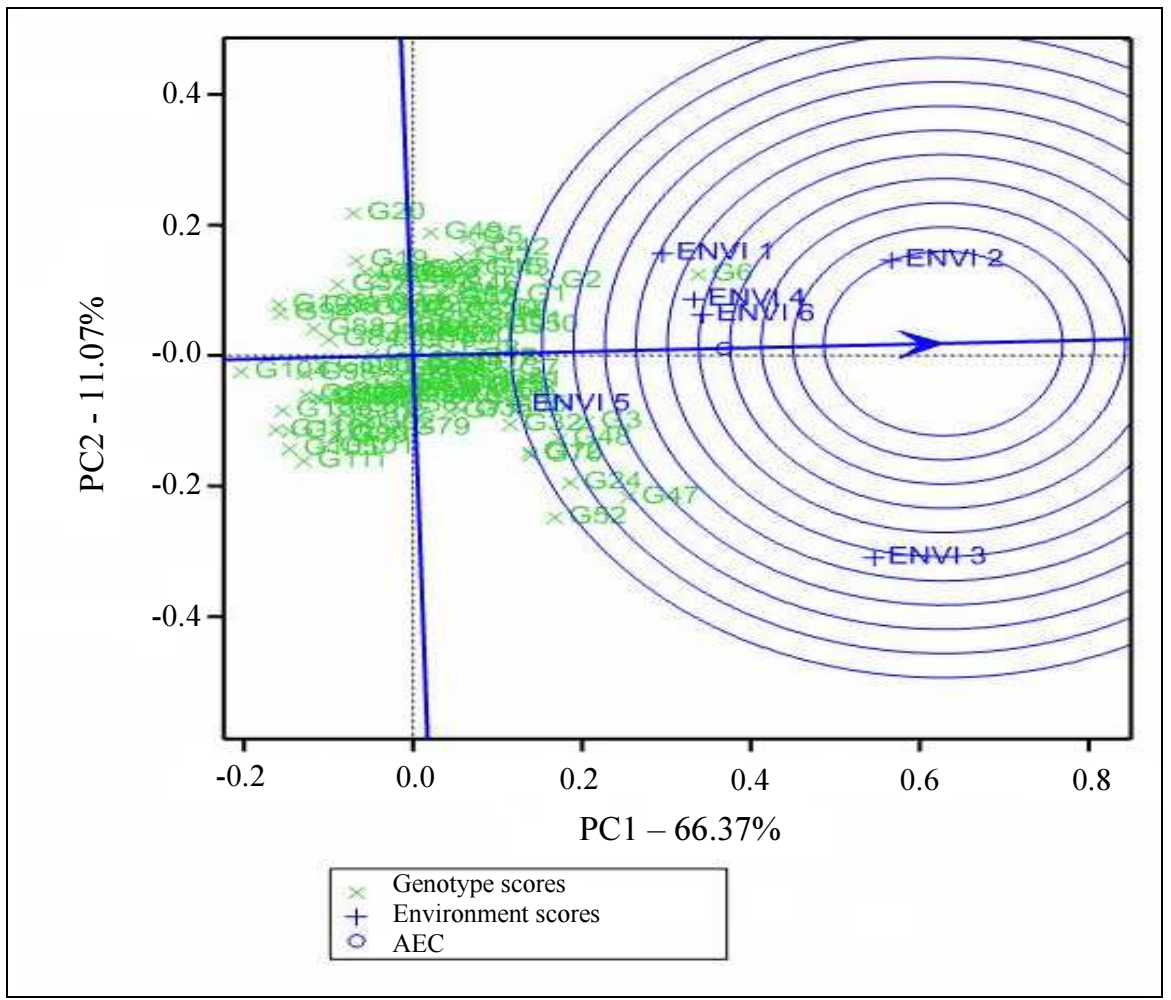

Fig. 4: Biplot for comparison of all environments with the ideal environment constructed based on environment-centred and environment-focused singular-value partitioning 


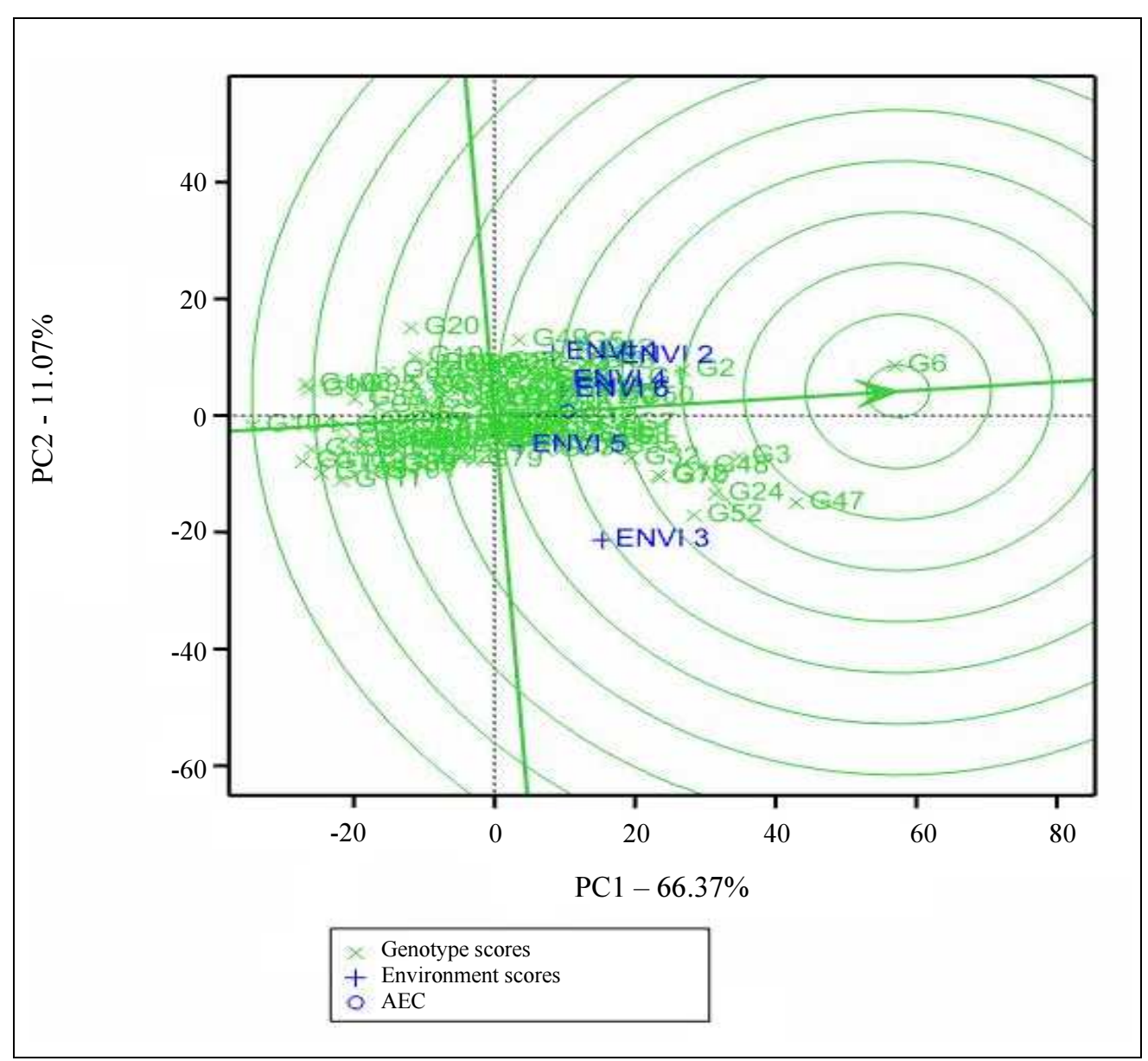

Fig. 5: Biplot showing comparison of all genotypes with ideal genotype constructed based on environment-centred and genotypefocused singular-value partitioning.

\section{Discussion}

The paper reports the progress made by the Kenya Agricultural and Livestock Research Organization (KALRO) potato breeding programme at Tigoni, Limuru in re-introducing cross breeding activities to develop new potato varieties. Though new varieties have not been released, promising results have been received so far. The fourth clonal generation had higher mean yield (35.7 ton $\mathrm{ha}^{-1}$ ) than the third clonal generation (33.1 ton $\mathrm{ha}^{-1}$ ) possibly due to the higher rainfall which were experienced during the fourth clonal generation or the cooler temperatures or both. Generally, long rains seasons in the Kenyan highlands have higher rainfall and cooler temperatures than the short rains seasons; the trend is also evidenced in the advanced yield trials (Table 6). Consequently, potato being a $\mathrm{C}_{3}$ cool season crop is likely to benefit more from the cool temperatures (Haverkort et al., 1990). Alternatively, it could be due to increase in size of seed tuber planted as clonal generations progressed. Studies have shown an association between the weight of tuber planted and the resulting yield (Brown and Caligari, 1986). Among the five high yielding clones, four of them had CIP clone 394895.7 (E) as the female parent (Table 8). It appears this clone had a high general combining ability for yield. In the stability studies, the clones were ranked differently which indicated crossover GEI (Table 6). This inconsistency in ranking could be due to clone $\mathrm{x}$ site, clone $\mathrm{x}$ season and clone $\mathrm{x}$ site $\mathrm{x}$ season interactions. The GEI makes it difficult to recommend a given clone to a specific area. Consequently, more dependable information will be generated when the National Performance Trials (NPT) are done on selected clones. This is because a high yielding generally adapted potato variety would be desirable for production in the major potato growing regions. From the AMMI analysis (Table 5), the first two IPCA's were significant $(\mathrm{p} \leq 0.001)$ and they accounted for $60.62 \%$ of the $G \times E$ interaction. This corroborates with previous findings that $\mathrm{G} \times \mathrm{E}$ data sets are best described by AMMI models with one or two multiplicative terms (Gauch and Zobel, 1988). 


\begin{tabular}{llll}
\multicolumn{5}{l}{ Table 8: Potato clones selected after advanced yield trials } & & \\
\hline Clone & Mean yield $\left(\mathrm{t} \mathrm{ha}^{-1}\right)$ & Fresh cooking & Chipping \\
\hline 2E87 & & & $\mathrm{X}$ \\
4C19 & 51.81 & $\mathrm{X}$ & $\mathrm{X}$ \\
1EY & 48.1 & & $\mathrm{X}$ \\
1EX & 45.49 & & $\mathrm{X}$ \\
2E68 & 42.98 & & $\mathrm{X}$ \\
1F15 & & $\mathrm{X}$ & $\mathrm{X}$ \\
1EU & 42.61 & $\mathrm{X}$ & \\
6B170 & 42.15 & & $\mathrm{X}$ \\
3E03 & 40.84 & $\mathrm{X}$ & \\
1HG & 40.08 & $\mathrm{X}$ & \\
5C39 & 39.38 & $\mathrm{X}$ & $\mathrm{X}$ \\
5E17 & 39.38 & $\mathrm{X}$ & \\
6D47 & 39.31 & $\mathrm{X}$ & \\
6D10 & 39.26 & $\mathrm{X}$ & \\
3C22 & 38.99 & & \\
1G53 & 38.62 & & \\
6D45 & 38.58 & & \\
6CB & 37.02 & & \\
\hline
\end{tabular}

Based on the yield data across the test environments (AYT) and the suitability for crisping and chipping, 18 potato clones were selected (Table 8). Among them, 11 $(61.11 \%)$ have good crisping quality. These 18 clones were recommended for the National Performance Trials (NPT) before release of new varieties.

\section{Conclusion}

From the foregoing, it is likely that KALRO-Tigoni will release high yielding potato varieties soon. I addition, release of new crisping and chipping varieties will be a boost to the local processing sector which is expanding fast.

\section{Acknowledgement}

The authors thank the Alliance for a Green Revolution in Africa (AGRA) for funding these breeding activities and the former Centre Director, KARI-Tigoni for technical assistance and constructive criticism that made this work a success.

\section{Author's Contributions}

Jane Muthoni: She designed the project, did all the field work and data collection. She wrote the paper.

Hussein Shimelis: He did data analysis and critically reviewed the paper. He approved the paper to be submitted in the current form.

\section{Ethics}

The authors hereby confirm that this manuscript is original work and do not contain any conflict of interest.

\section{References}

ANN, 2009. Kenya to give renewed attention to potato cultivation. Africa News Network, Nairobi, Kenya.

Brown, J. and P.D.S. Caligari, 1986. The efficiency of seedling selection for yield and yield components in a potato breeding programme. Pflanzenzucht.

Cooper, M., R.M. Stuker, I.H. Delacy and B.D. Harch, 1997. Wheat breeding nurseries, target environments and indirect selection for grain yield. Crop Sci., 37: 1168-1176. DOI: 10.2135/cropsci1997.0011183X003700040024x

Crossa, J., 1990. Statistical analyses of multilocation trials. Adv. Agronomy, 44: 55-85. DOI: $10.1016 / \mathrm{S} 0065-2113(08) 60818-4$

FAO, 2013. A policymakers'guide to crop diversification: The case of the potato in Kenya. Food and Agriculture Organisation of the United Nations, Rome, Italy.

FAO, 2014. The potato sector. Food and Agriculture Organisation of the United Nations, Rome, Italy.

Gauch, H.G. and R.W. Zobel, 1988. Predictive and postdictive success of statistical analyses of yield trials. Theoretical Applied Genet., 76: 1-10. DOI: $10.1007 /$ BF00288824

Gregory, J.S., L. Ricardo and, V. Suarez, 2013. Booms, busts and emerging markets for potatoes in East and Central Africa 1961-2010. Potato Res., 56: 205-236 DOI: $10.1007 / \mathrm{s} 11540-013-9240-2$

Haverkort, A.J., M. van de Waart and K.B.A. Bodlaender, 1990. The effect of early drought stress on numbers of tubers and stolons of potato in controlled and field conditions. Potato Res., 33: 89-96. DOI: 10.1007/BF02358133 
Jaetzold, R., H. Schmidt, B. Hornetz and C. Shisanya, 2006. Farm Management Handbook of Kenya: Natural Conditions and Farm Management Information. 2nd Edn., Ministry of Agriculture, Nairobi, Kenya.

Kang, M.S., 1993. Simultaneous selection for yield and stability in crop performance trials: Consequences for growers. Agronomy J., 85: 754-757.

DOI: 10.2134/agronj1993.00021962008500030042x

KARI, 2008. Production of food (ware) potatoes. KARI information brochure. Kenya Agricultural Research Institute, Nairobi, Kenya.

MoALF, 2016. The national potato strategy. Ministry of Agriculture, Livestock and Fisheries, Nairobi, Kenya.

MoA, 1998. Postharvest systems of potato and sweet potato in Kenya. Final Report. Ministry of Agriculture, Nairobi, Kenya.

MoA, 2005. National policy on potato industry. Policy and reforms in the industry to improve production, research, marketing and regulatory framework. Ministry of Agriculture, Nairobi, Kenya.

MoA, 2008. National policy on potato industry. Policy reforms to revitalize the potato industry Ministry of Agriculture, Nairobi, Kenya.

Muthoni, J., H. Shimelis and R. Melis, 2013. Potato production in Kenya: Farming systems and production constraints. J. Agric. Sci., 5: 182-197. DOI: $10.5539 /$ jas.v5n5p182

Muthoni, J., H. Shimelis, R. Melis and Z.M. Kinyua, 2014. Response of potato genotypes to bacterial wilt caused by Ralstonia solanacearum (Smith) (Yabuuchi et al.) in the tropical highlands. Am. J. Potato Res., 91: 215-232. DOI 10.1007/s12230-013-9340-1
NPCK, 2014. The potato crop. National Potato Council of Kenya, Nairobi, Kenya.

Payne, R.W., D.A. Murray, S.A. Harding, D.B. Baird and D.M. Soutar, 2011. GenStat for Windows. 14th Edn., VSN International, Hemel Hempstead, UK.

PSDA, 2009. National potato taskforce report. Final Report. Promotion of Private Sector Development in Agriculture Programme. Ministry of Agriculture and Deutsche Gessellschaft fur Technische Zusammenarbeit, Nairobi, Kenya.

Riungu, C., 2011. No easy walk for potatoes. Horticultural News. East African Fresh Produce J., 19: 16-17.

SAS, I., 2003. SAS user's guide. In Statistics. Cary, NC, USA.

Yan, W., L.A. Hunt, Q. Sheng and Z. Szlavnics, 2000. Cultivar evaluation and mega-environment investigation based on the GGE Biplot. Crop Sci., 40: 597-605. DOI: $10.2135 /$ cropsci2000.403597x

Yan, W., 2002. Singular-value partitioning in biplot analysis of multienvironment trial data. Agronomy J., 94: 990-996. DOI: 10.2134/agronj2002.0990

Yan, W. and M.S. Kang, 2003. GGE Biplot Analysis: A Graphical Tool for Breeders, Geneticists and Agronomists. 1st Edn., RCR Press, New York, ISBN-10: 1420040375, pp: 288.

Yan, W., P.L. Cornelius, J. Crossa and L.A. Hunt, 2001. Two types of GGE Biplots for analyzing multienvironment trial data. Crop Sci., 41: 656-663. DOI: $10.2135 /$ cropsci2001.413656x

Yan, W., B.M. Kang, S. Woods and P.L. Cornelius, 2007. GGE biplot Vs AMMI analysis of genotype-bygenotype environment data. Crop Sci., 47: 643-655. DOI: $10.2135 /$ cropsci2006.06.0374 